\title{
LAPORAN KASUS: TIGA NEONATUS YANG LAHIR DARI IBU YANG TERINFEKSI COVID 19 DI RSUD. UNDATA PALU DINYATAKAN POSITIF COVID 19, PENULARAN MELALUI VERTIKAL IBU KE JANIN ATAU KARENA LINGKUNGAN
}

\author{
Indah Fitriyani \\ RSUD. UNDATA Palu Sulawesi Tengah Indonesia, \\ drindahfitriyani@gmail.com
}

Received: 03-05-2021

Revised: 16-05-2021

Accepted: 22-05-2021

\section{Abstract}

Background: The SARS-CoV-2 outbreak is a pandemic that began in 2019 and first occurred in Wuhan, China. SARSCoV-2 infection causes a new coronavirus disease (COVID19) and is mostly transmitted through droplets, but other ways of transmission are still hypothetical. Some cases of perinatal transmission have been described, but it is unclear whether this occurs through transplasentic or transservistic pathways or through environmental exposure. It is important to clarify whether and how SARS-CoV-2 reaches the fetus, to prevent neonatal infections, optimize pregnancy management and ultimately better understand the biology of SARS-CoV-2. We reported the case of three positively confirmed newborns through PCR SARS-CoV-2 examination from December 2020 - January 2021 at the hospital. UNDATA Palu Central Sulawesi.

Keywords: Positive newborns Covid 19; Covid 1;

Transmission of Covid 19 to newborns.

\begin{abstract}
Abstrak
Wabah SARS-CoV-2 adalah pandemi yang dimulai sejak 2019 dan pertama kali terjadi di Wuhan, China. Infeksi SARS-CoV-2 menyebabkan penyakit coronavirus baru (COVID-19) dan sebagian besar ditularkan melalui droplet, tetapi cara penularan lain masih bersifat hipotesis. Beberapa kasus penularan perinatal telah dijelaskan, tetapi tidak jelas apakah ini terjadi melalui jalur transplasenta atau transervikal atau melalui paparan lingkungan. Penting untuk mengklarifikasi apakah dan bagaimana SARS-CoV-2 mencapai janin, untuk mencegah infeksi neonatal, mengoptimalkan manajemen kehamilan dan pada akhirnya lebih memahami biologi SARS-CoV-2. Kami melaporkan kasus adanya tiga bayi baru lahir yang terkonfirmasi posistif melalui pemeriksaan PCR SARS-CoV-2 dari bulan Desember 2020 - bulan Januari 2021 di RSUD.UNDATA Palu Sulawesi Tengah.
\end{abstract}

Kata kunci: Bayi baru lahir positif Covid 19; Covid 19; Penularan Covid 19 ke bayi baru lahir. 
Coresponden Author : Indah Fitriyani ${ }^{1}$

Email : drindahfitriyani@gmail.com

CC BY ND

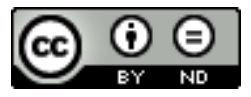

\section{PENDAHULUAN}

Baru-baru ini, wabah pneumonitis virus di Wuhan, Hubei, China secara berturutturut menyebar sebagai pandemia global, menyebabkan identifikasi spesies betacoronavirus baru, novel coronavirus 2019, yang secara berturut-turut ditetapkan 2019-nCoV kemudian SARS-CoV-2). SARS-CoV-2 menyebabkan sindrom klinis yang ditunjuk coronavirus disease 2019 (COVID19) dengan spektrum manifestasi mulai dari infeksi saluran pernapasan atas ringan hingga pneumonitis berat, sindrom gangguan pernapasan akut (ARDS) dan kematian. Beberapa kasus telah diamati pada anak-anak dan remaja yang tampaknya memiliki klinis yang lebih menguntungkan daripada kelompok usia lainnya, dan bahkan lebih sedikit pada bayi yang baru lahir (De Rose et al., 2020).

Risiko penularan vertikal dari wanita hamil yang terinfeksi ke janinnya masih kontroversial. Resiko penularan intrauterin menjadi perhatian khusus karena SARS-CoV2 menggunakan reseptor ACE 2 untuk masuk ke sel, dan diketahui bahwa terdapat ekspresi reseptor ACE 2 di plasenta manusia. Dua penelitian yang baru-baru ini diterbitkan telah memberikan bukti tentang potensi penularan vertikal. Dalam sebuah laporan oleh Zamaniyan et al, terdapat bukti potensi infeksi intrauterine pada wanita dengan COVID-19 parah yang melahirkan pada usia kehamilan 32 minggu seperti yang ditunjukkan oleh hasil tes RT-PCR positif untuk COVID-19 dalam cairan ketuban dan ulangan. usap hidung dan tenggorokan neonatal; usapan neonatal awal, serta sekresi vagina dan darah tali pusat negatif untuk COVID-19 (Algarroba et al., 2020).

Pemeriksaan real time PCR telah merevolusi cara laboratorium mikrobiologi klinis mendiagnosis banyak infeksi mikroba manusia. Metode pengujian ini menggabungkan kimia PCR dengan deteksi probe fluoresen dari produk yang diperkuat dalam bejana reaksi yang sama (Espy et al., 2006).

\section{METODE PENELITIAN}

Bagian metode harus dapat menjelaskan metode penelitian yang digunakan, termasuk bagaimana prosedur pelaksanaannya. Alat, bahan, media atau isntrumen penelitian harus dijelaskan dengan baik. Apabila ada rumus statistika yang digunakan sebagai bagian dari metode penelitian, sebaiknya tidak menuliskan rumus yang sudah berlaku umum.

\section{HASIL DAN PEMBAHASAN}

\section{A. Hasil Penelitian}

Bayi pertama dilahirkan dari ibu dengan swab PCR terkonfirmasi positif Covid 19 tanggal 7 Desember 2020 secara sectio cesaria dengan indikasi ketuban pecah dini. Berat 
badan bayi 3300 gram, apgar score menit pertama 7, menit ke lima 8, dilakukan pemeriksaan swab PCR 12 jam setelah lahir dan hasilnya positif, selama observasi bayi tidak memiliki gejala sakit.

Bayi kedua dilahirkan dari ibu dengan swab antigen Covid 19 positif dan swab PCR terkonfirmasi positif Covid 19 tanggal 2 Januari 2021 secara sectio cesaria dengan indikasi cephalopelvic disproportion (CPD), berat badan bayi 3300 gram, apgar score menit pertama 7, menit ke lima 8, dilakukan swab PCR 12 jam setelah lahir dan hasilnya positif, selama observasi bayi tidak memiliki gejala sakit.

Bayi ketiga dilahirkan dari ibu dengan swab PCR terkonfirmasi positif Covid 19 tanggal 8 Januari 2021 secara sectio cesaria dengan indikasi plasenta previa letak rendah, berat badan bayi 3450 gram, apgar score menit pertama 4, menit ke lima 5, dan menit ke sepuluh adalah 8, dilakukan pemeriksaan swab PCR 12 jam setelah lahir dan hasilnya negatif, pemeriksaan swab PCR ke dua dilakukan 24 jam setelah bayi lahir dan hasilnya didapatkan positif, selama observasi bayi tidak memiliki gejala sakit.

Ketiga bayi setelah dilahirkan, langsung dipisahkan dari ibu mereka dan dilakukan perawatan di ruang perawatan bayi.

\section{B. Pembahasan}

Penting untuk mempelajari semua neonatus yang dilahirkan dari ibu positif COVID-19 untuk menganalisis rute penularan infeksi yang akan mengoptimalkan pengujian universal untuk SARS-CoV-2 dan meminimalkan risiko penyakit pada neonatus (Huseynova et al., 2021).

Bayi di bawah usia 1 tahun mungkin berisiko lebih tinggi terkena penyakit parah dengan COVID-19 daripada anak yang lebih tua. Ini mungkin karena sistem kekebalan mereka yang belum matang dan saluran udara yang lebih kecil, yang membuat mereka lebih mungkin mengembangkan masalah pernapasan dengan infeksi virus pernapasan (Dong et al., 2020).

Pada 22 Februari, seorang bayi perempuan dilahirkan melalui operasi caesar di ruang isolasi bertekanan negatif. Ibunya mengenakan masker N95 dan tidak menggendong bayinya. Berat lahirnya adalah 3120 g dan skor Apgar adalah 9 pada 1 menit dan 10 pada 5 menit. Neonatus tidak memiliki gejala dan segera dikarantina di unit perawatan intensif neonatal. Pada umur 2 jam kadar IgG SARS-CoV-2 sebesar 140,32 AU / mL dan kadar IgM sebesar 45,83 AU / mL. Sitokin meningkat (IL-6, 28,26 pg / mL; IL-10, 153,60 pg / mL), serta jumlah sel darah putih 18,08 × 109 / L. CT dada normal. Neonatus tersebut dipindahkan ke rumah sakit anak-anak sesuai protokol. Hasil dari 5 tes RT-PCR pada usap nasofaring yang diambil dari usia 2 jam sampai 16 hari adalah negatif. Kadar IgM (11,75 AU / mL) dan IgG $(69,94 \mathrm{AU} / \mathrm{mL})$-nya masih meningkat pada 7 Maret (Tabel 2), dan dia dipulangkan pada 18 Maret (Nash, 2021).

Penularan SARS-CoV-2, virus yang menyebabkan COVID-19, kepada neonatus diperkirakan terjadi terutama melalui tetesan pernapasan selama periode pascakelahiran ketika neonatus terpapar pada ibu atau pengasuh lain dengan infeksi SARS-CoV-2. Laporan terbatas dalam literatur telah menimbulkan kekhawatiran tentang kemungkinan penularan intrauterin, intrapartum, atau peripartum, tetapi luas dan signifikansi klinis dari penularan vertikal, yang tampaknya jarang, tidak jelas. Saat ini, tidak ada cukup data untuk membuat rekomendasi tentang penjepitan tali pusat yang tertunda secara rutin atau perawatan kulit-ke-kulit segera untuk tujuan mencegah penularan SARS-CoV-2 ke neonatus (Vivanti et al., 2020).

Beberapa kasus penularan perinatal telah dipaparkan tetapi tidak jelas apakah ini terjadi melalui jalur transplasenta atau transervikal atau melalui paparan lingkungan. Penting untuk mengklarifikasi apakah dan bagaimana SARS-CoV-2 mencapai janin, 
untuk mencegah infeksi neonatal, mengoptimalkan manajemen kehamilan dan pada akhirnya lebih memahami biologi SARS-CoV-2 (Vivanti et al., 2020).

Data ibu dan bayi baru lahir dari wanita hamil dengan COVID-19, termasuk penularan vertikal, masih terbatas saat ini. Dua penelitian baru-baru ini melaporkan tiga neonatus dengan peningkatan antibodi IgG dan IgM terhadap SARS-CoV-2 yang lahir dari wanita hamil COVID-19 yang dikonfirmasi meskipun pemeriksaan RNA SARS$\mathrm{CoV}-2$ melalui real-time reverse transcription-polymerase chain reaction (SARS-CoV-2) pada bayi baru lahir negatif. Namun, banyak dari kasus ini yang diduga terinfeksi setelah melahirkan atau setelah kontak dengan orang tua atau pengasuh yang positif COVID-19. Salah satu dari 116 pasien terbesar melaporkan tidak ada penularan vertikal COVID-19 ke neonatus selama trimester ketiga (Moreno et al., 2020).

Kedokteran laboratorium memainkan peran penting dalam deteksi dini, diagnosis, dan pengelolaan penyakit COVID-2019, di mana reaksi berantai polimerase reverse-transkripsi waktu nyata (rRT-PCR) memungkinkan identifikasi virus langsung. Diagnosis molekuler menggunakan reverese-transcription RT-PCR adalah pendekatan paling konklusif saat ini untuk diagnosis COVID-19. Meskipun banyak penelitian belum mendeteksi SARS-CoV-2 dalam cairan ketuban oleh RT-PCR, laporan yang baru-baru ini diterbitkan dari Iran menggambarkan deteksi SARS-CoV-2 dalam sampel cairan ketuban yang diperoleh selama operasi caesar dari ibu dengan COVID-19 parah yang kemudian meninggal. RT-PCR pada usap hidung dan tenggorokan pada neonatus setelah melahirkan negatif, tetapi tes kedua 24 jam kemudian positif.

Penularan vertikal SARS-CoV-2 belum terbukti hingga saat ini, rangkaian kasus dan laporan difokuskan pada bayi yang lahir dari ibu dengan gejala positif. Rose et al. meninjau delapan seri kasus dengan total 69 wanita hamil yang melahirkan 70 bayi. Hanya empat dari 63 bayi yang diuji memiliki usapan tenggorokan positif. Seri terbesar hingga saat ini adalah studi kohort nasional Sistem Pengawasan Kebidanan Inggris. Dalam rangkaian ini dari 427 wanita hamil yang dirawat di rumah sakit karena SARSCoV-2, 247 melahirkan atau mengalami keguguran. 12 bayi dinyatakan positif; enam di antaranya dalam dua belas jam pertama. Tidak ada deskripsi tentang teknik pengendalian infeksi yang dipraktikkan oleh ibu yang diberikan.

Ada beberapa laporan infeksi plasenta pada wanita yang bergejala COVID-19 positif. Dua kasus trimester tengah dijelaskan dengan janin yang dapat hidup di mana RNA virus positif dari permukaan plasenta tetapi tidak dari janin. Penfield dkk. menjelaskan usapan plasenta dan membran yang dikirim pada sebelas pasien positif COVID-19, tiga di antaranya positif meskipun tidak ada bayi yang dinyatakan positif pada hari pertama hingga lima kehidupan.

(Chen et al., 2020) Melakukan penelitian dan fokus utama penelitian mereka adalah menyelidiki kemungkinan penularan infeksi COVID-19 intrauterin. Mereka memilih untuk menguji sampel cairan ketuban, darah tali pusat, dan usap tenggorokan neonatal saat lahir untuk memastikan kemungkinan infeksi janin intrauterin. Khususnya, semua sampel yang diuji dalam penelitian dikumpulkan di ruang operasi pada saat operasi caesar, sehingga menjamin bahwa sampel tidak terkontaminasi dan paling mewakili kondisi intrauterin janin. Hasil menunjukkan bahwa SARS-CoV-2 negatif pada semua sampel di atas, menunjukkan bahwa tidak ada infeksi janin intrauterine yang terjadi akibat infeksi COVID-19 selama tahap akhir kehamilan. Temuan mereka sesuai dengan apa yang diamati pada SARS, yang memiliki urutan serupa dengan SARS-CoV-2. Penelitian sebelumnya telah menunjukkan tidak ada bukti infeksi SARS perinatal pada bayi yang lahir dari ibu yang mengalami infeksi SARS selama kehamilan.

Meskipun, spesimen usap nasofaring untuk SARS - CoV - 2 oleh RT - PCR dianggap sebagai salah satu cara terbaik untuk mengkonfirmasi COVID-19; namun, sebagian besar penelitian tidak mengungkapkan adanya SARS - CoV - 2 RNA dalam 
spesimen seperti cairan ketuban, darah tali pusat, ASI, atau cairan vagina. Udugama dkk menyarankan bahwa hasil dapat dipengaruhi oleh viral load, teknik sampel, atau tahap penyakit awal.

Sebanyak 46 pasangan ibu-bayi telah diuji sampel ASInya untuk COVID-19. Semua ibu memiliki COVID-19, sementara 13 bayi dinyatakan positif COVID-19. Sampel ASI dari 43 ibu negatif untuk virus COVID-19 sedangkan sampel dari 3 ibu dinyatakan positif partikel virus dengan RT-PCR. Di antara 3 bayi yang ASI ibunya dites positif untuk partikel RNA virual, bukan virus hidup, satu bayi dinyatakan positif COVID-19 tetapi praktik pemberian makan bayi tidak dilaporkan. Dua bayi lainnya dinyatakan negatif COVID-19; satu disusui, dan bayi lainnya diberi ASI perah setelah partikel RNA virus tidak lagi terdeteksi. Pada anak tunggal dengan COVID-19, tidak jelas jalur atau sumber mana bayi terinfeksi, yaitu melalui ASI atau tetesan dari kontak dekat dengan ibu yang terinfeksi.

Chen dkk. tidak menemukan SARS-CoV-2 dalam cairan ketuban yang dikumpulkan dari enam wanita yang terinfeksi. Weiyong dkk. menguji plasenta dan lendir vagina ibu, hasilnya negatif. Wang dkk. memperoleh hasil tes virus-negatif dalam cairan ketuban, plasenta dan darah tali pusat dari wanita yang terinfeksi.

Maksim dkk melaporkan seorang wanita berusia 40 tahun, G2P1 dirawat di rumah sakit tersier di Toronto, Ontario. Pasien ini menderita neutropenia, diabetes gestasional, dan riwayat infeksi bakteri yang sering, termasuk sinusitis, infeksi kulit, dan bronkitis selama kehamilan ini, yang diatasi dengan pengobatan antibiotik. Pasien mengalami mialgia, nafsu makan menurun, kelelahan, batuk kering dan suhu $39^{\circ} \mathrm{C}$ dalam 24 jam sebelumnya. Usap nasofaring positif untuk target gen yang dicurigai sindrom pernapasan akut parah virus corona 2 (SARS-CoV-2) melalui pengujian reverse transcription polymerase chain reaction (RT-PCR). Tidak ada kegawatan janin selama kehamilan atau setelah masuk RS. Pasien tersebut tidak membutuhkan alat bantu pernapasan saat melahirkan. Kelahiran sesar dilakukan dengan anestesi regional, dengan kewaspadaan melalui udara, tetesan dan kontak. Ketuban pecah secara artifisial dilakukan saat operasi. Cairan ketubannya bening. Bayi laki-laki lahir tidak membutuhkan resusitasi. Skor Apgarnya adalah 9 pada 1 menit dan 9 pada 5 menit, dan berat lahirnya adalah 2,93 kg. Sesuai dengan SOP, penjepitan tali pusat yang tertunda tidak dilakukan, dan neonatus segera dipindahkan dari lapangan operasi secara steril, ke resusitator yang berjarak $2 \mathrm{~m}$ di ruangan yang sama. Usap plasenta (sisi ibu dan janin) diperoleh. Jaringan plasenta dikirim untuk PCR dan pemeriksaan histopatologi. Usap nasofaring diambil dari neonatus pada hari lahir, hari ke-2 dan ke-7, setelah bayi dibersihkan secara menyeluruh dan sebelum kontak dengan ibu. Ketiga usap nasofaring neonatus itu positif untuk target gen SARS-CoV-2 melalui pengujian RT-PCR; plasma neonatal dinyatakan positif pada hari ke-4, dan tinja positif pada hari ke-7.

Ada tantangan signifikan untuk mengembangkan tes sensitif dan spesifik untuk mendiagnosis COVID-19 yang disebabkan oleh infeksi virus RNA, sindrom pernapasan akut parah, coronavirus 2 (SARS-CoV-2). Diagnosis COVID-19 pada stadium akut bergantung pada pendeteksian RNA genomik SARS-CoV-2 pada usap naso / oropharyngeal (NOP). Usap dipindahkan ke laboratorium baik dalam media transportasi virus atau universal (VTM / UTM) dan reverse transcriptase PCR (RT-PCR) dilakukan untuk mendeteksi SARS-CoV-2 RNA.

Mempertimbangkan transmisi vertikal virus pernapasan dari ibu ke anak, ada tiga pola potensial: transplasenta selama kehamilan, melalui jalan lahir selama persalinan dan menyusui pascapartum. Bukti yang diperoleh hingga saat ini menunjukkan bahwa tidak terjadi penularan vertikal virus corona dari ibu hamil ke janin.

Keterbatasan dari laporan kasus ini adalah tidak dilakukan pemeriksaan lebih lanjut terhadap air ketuban, darah tali pusat, ataupun plasenta. Pemeriksaan tambahan 
terhadap sampel ibu dan bayi baru lahir harus dilakukan untuk memastikan observasi awal. Jadi, tidak bisa ditarik kesimpulan bahwa ketiga bayi ini terinfeksi secara vertikal dari ibunya.

\section{KESIMPULAN}

Meskipun COVID-19 pada wanita hamil dan neonatusnya telah dibuktikan, tidak ada cukup bukti tentang bagaimana penularan vertikal dari wanita hamil yang terinfeksi Covid 19 ke janinnya.

\section{BIBLIOGRAPHY}

Domenico Umberto De Rose, F. P. (2020, April 29). Novel Coronavirus disease (COVID19) in newborns and infants: what we know so far. Retrieved March 03, 2021, from Italian Journal of Pediatrics: https://ijponline.biomedcentral.com/articles/10.1186/s13052-020-0820-x

Gabriela N. Algarroba, M. (2020, Agustus). Visualization of severe acute respiratory syndromecoronavirus 2 invading the human placenta usingelectron microscopy Retrieved maret Friday, 2021, from American Journal of Obstetrics \& Gynecology: https://www.ajog.org/article/S0002-9378(20)30549-4/pdf

Espy, M. J. (2006, January). Real-Time PCR in Clinical Microbiology: Applications for Routine Laboratory Testing. Retrieved March Tuesday, 2021, from American Society For Microbiology: https://www.ncbi.nlm.nih.gov/pmc/articles/PMC1360278/

al, R. A. (2021, February 10). A neonate born to an infected COVID-19 mother was tested positive just 24 hours after its birth. Retrieved March 03, 2021, from Wiley Online Library: https://doi.org/10.1002/ccr3.3913

staff, M. C. (2021, April 2). COVID-19 (coronavirus) in babies and children. Retrieved April 27, 2021, from Mayo Clinic: https://www.mayoclinic.org/coronavirus-inbabies-and-children/art-20484405

Dong, L et al. (2020, March 26). Possible Vertical Transmission of SARS-CoV-2 From an Infected Mother to Her Newborn. Retrieved April 28, 2021, from US National Libary of Medicine National Institutes of Health: https://www.ncbi.nlm.nih.gov/pmc/articles/PMC7099527/

Care for Newborns. (2020, December 8). Retrieved April 27, 2021, from Centers for Disease Control and Prevention: https://www.cdc.gov/coronavirus/2019ncov/hcp/caring-for-newborns.html

Alexandre J. Vivanti et al. (2020, July 14). Transplacental transmission of SARS-CoV-2 infection. Retrieved march 3, 2021, from Nature Communications : https://www.nature.com/articles/s41467-020-17436-6

Laporan Kasus: Tiga Neonatus Yang Lahir Dari Ibu Yang Terinfeksi Covid 19 Di Rsud. Undata Palu Dinyatakan Positif Covid 19, Penularan Melalui Vertikal Ibu Ke Janin Atau Karena 
Moreno, S. C et al. (2020, November 12). Vertical Transmission of COVID-19 to the Neonate . Retrieved April 27, 2021, from National Library of Medicine: https://pubmed.ncbi.nlm.nih.gov/33273803/

Plebani, G. L. (2020). Laboratory abnormalities in patients with COVID-2019 infection. Retrieved March 03, 2021, from De Gruyter: https://www.degruyter.com/document/doi/10.1515/cclm-2020-0198/html

Uhteg, K, et al. (2020, April 26). Comparing the analytical performance of three SARSCoV-2 molecular diagnostic assays . Retrieved March 03, 2021, from Pubmed.gov: https://pubmed.ncbi.nlm.nih.gov/32361285/

Perinatol., A. J. (2020, Juny 5). Vertical Transmission of SARS-CoV-2: What is the Optimal Definition? Retrieved March 03, 2021, from US National Library of Medicine National Institutes of Health: https://www.ncbi.nlm.nih.gov/pmc/articles/PMC7356079/

McDevitt, K. E. (2020, Juny 19). Outcome of universal screening of neonates for COVID-19 from asymptomatic mothers. Retrieved March 03, 2021, from PMC US National Library of Medicine National Institutes of Health: https://www.ncbi.nlm.nih.gov/pmc/articles/PMC7303651/

Solis, G et al. (2021, March 1). Epidemiology, management and risk of SARS-CoV-2 transmission in a cohort of newborns born to mothers diagnosed with COVID19 infection. Retrieved April 27, 2021, from Anales de pediatria: https://www.analesdepediatria.org/en-epidemiology-management-risk-sars-cov2-transmission-articulo-S2341287921000090

Huijun Chen, $\mathrm{P}$ et al. (2020, February 12). Clinical characteristics and intrauterine vertical transmission potential of COVID-19 infection in nine pregnant women: a retrospective review of medical records. Retrieved March 03, 2021, from US National Library of Medicine National Institutes of Health: https://www.ncbi.nlm.nih.gov/pmc/articles/PMC7159281/?report=reader).

Breastfeeding and COVID-19. (2020, June 23). Retrieved April 27, 2021, from World Health Organization: https://www.who.int/newsroom/commentaries/detail/breastfeeding-and-covid-19

Rajewska, A. (2020, May 11). COVID-19 and pregnancy - where are we now? A review. Retrieved April 28, 2021, from https://doi.org/10.1515/jpm-2020-0132

Kritsman, M et al. (2020, May 14). Probable congenital SARS-CoV-2 infection in a neonate born to a woman with active SARS-CoV-2 infection. Retrieved April 29, 2021, from US National Library of Medicine National Institute of Health: https://www.ncbi.nlm.nih.gov/pmc/articles/PMC7828840/

Payne, D. (2020). Preanalytical issues affecting the diagnosis of COVID-19. Retrieved March 03, 2021, from Journal of Clinical Pathology: http://dx.doi.org /10.1136/jclinpath-2020-206751

(C) 2021 by the authors. Submitted for possible open access publication under the terms and conditions of the Creative Commons Attribution (CC BY ND) license (https://creativecommons.org/licenses/by/3.0/).

Laporan Kasus: Tiga Neonatus Yang Lahir Dari Ibu Yang Terinfeksi Covid 19 Di Rsud. Undata Palu Dinyatakan Positif Covid 19, Penularan Melalui Vertikal Ibu Ke Janin Atau Karena Lingkungan 